\title{
HILL v. REGISTRAR: LIMITATION OF ACTIONS, THE ASSURANCE FUND AND THE "DISCOVERABILITY" RULE
}

\section{W.H. HURLBURT}

\section{SCOPE OF HILL V. REGISTRAR'}

Since City of Kamloops v. Nielsen ${ }^{2}$ and Central Trust Company v. Rafuse, ${ }^{3}$ there has been "a general rule that a cause of action arises for purposes of a limitation period when the material facts on which it is based have been discovered or ought to have been discovered by the plaintiff by the exercise of reasonable diligence. ${ }^{44}$ The judgment of the Court of Appeal in Hill ${ }^{5}$ suggests that the rule should not be interpreted too broadly. It also clarifies what it is that confers a cause of action for "deprivation" of land under section 158 of the Land Titles Act. ${ }^{6}$

\section{FACTS}

The material facts of Hill were as follows:

1. In 1977, Mrs. Hill was the registered owner of a house property. In that year, the following registrations took place:

(a) a forged transfer in favour of A, followed immediately by a mortgage by $\mathrm{A}$ to a mortgage lender, the two documents having been delivered to the Registrar together for registration;

(b) a later transfer back to Mrs. Hill, which left the mortgage on her title.

Mrs. Hill knew nothing of these registrations and did not authorize any of them.

2. Before April 26, 1982, ${ }^{8}$ Mrs. Hill knew that the mortgage had been registered against her title. She was told by the Law Society that even if there had been wrongdoing by a lawyer (as she alleged at that time, though mistakenly) the mortgage would remain against her title and she should consult a lawyer.

\footnotetext{
Director Emeritus, Alberta Law Reform Institute and Counsel, Reynolds Mirth Richards \& Farmer. (1993), 135 A.R. 266 (C.A.) [hereinafter Hill].

[1984] S.C.R. 2 [hereinafter Kamloops]. [1986] 2 S.C.R. 147 [hereinafter Rafuse].

Rafuse, supra note 3 at 224. In this comment, something is "discoverable" if it has been discovered or ought to have been discovered by the plaintiff by the exercise of reasonable diligence. Something not within that category is not "discoverable. The "discoverability" rule is the rule quoted in the text to this footnote.

6. R.S.A. 1980, c. L-5 [hereinafter the Land Titles Act].

8. This date was six years before she commenced action against the Registrar.
}

3. Supra note 1 .

7. Supra note 1. 
3. In September 1982 the mortgage lender brought a foreclosure action under the mortgage. In December 1982 Mrs. Hill brought a counterclaim. In Hill, ${ }^{9}$ the Court of Appeal described the counterclaim as alleging that the mortgage was a forgery and nullity. The previous Court of Appeal judgment in the foreclosure action ${ }^{10}$ described it as alleging that there had been a fraudulent conspiracy.

4. In July 1985, following a trial in May of that year, the trial judge held that there was no conspiracy, so Mrs. Hill did not succeed on those grounds. However, he held that the mortgage did not bind the land because the mortgage lender had not dealt on the faith of the register. The reason for this finding was that the mortgage had been obtained and delivered to the Land Titles Office along with the forged transfer at a time when the register showed Mrs. Hill as the registered owner.

5. In December 1986, the Court of Appeal reversed the trial judge and held that the mortgage bound the land.

6. In May 1987 the Queen's Bench granted an order nisi in the mortgage action and in June it vested title in the mortgagee and ordered Mrs. Hill to vacate the property.

7. On April 26, 1988, Mrs. Hill started her action against the Registrar for payment of compensation from the assurance fund.

\section{WHEN MRS. HILL SUFFERED LOSS OR DEPRIVATION}

Mrs. Hill had had a valid claim for compensation from the assurance fund. That was not in dispute. The question for the Court of Appeal was whether she had brought her action to enforce the claim within the 6-year limitation period prescribed by section 168 of the Land Titles Act." This raised the following sub-questions:

1. when did Mrs. Hill's claim for compensation arise? The Court of Appeal's answer was that it arose in 1977 when the transfer and mortgage were registered.

2. if the claim arose for ordinary purposes more than 6 years before April 26, 1988, did the "discoverability" rule apply? The court did not answer this question, as its answer to question 3 made it unnecessary to do so because Mrs. Hill was out of time whether or not the "discoverability" rule applied.

3. if the "discoverability" rule did apply, were the material facts on which Mrs. Hill's claim was based discovered by her, or ought they have been discovered by her by the exercise of reasonable diligence, more than 6 years before April 26,1988 ? The court's answer was yes.

Some background discussion is necessary. 
The Land Titles $A c t^{12}$ is intended to make the acquisition of interests in land quick, easy, cheap and safe. By doing so, it detracts from security of ownership: it creates a risk that an owner will, due to mistake or fraud, lose his or her interest or have it subordinated to another interest. This is what happened to Mrs. Hill. The Act recognizes that risk. It accordingly provides a user-funded system of compensation for owners whose interests are improperly lost or subordinated.

Under that compensation system, an owner who suffers loss is entitled to be compensated from an "assurance fund" built up from users' contributions, or, more accurately, to be compensated from the General Revenue Fund to which almost all of the assurance fund is transferred. ${ }^{13}$ An owner whose claim is not settled by agreement may bring an action for compensation against the Registrar of the relevant Land Titles Office as a nominal defendant.

Section $158^{14}$ confers the right to compensation. It reads as follows:

158 Any person who sustains loss or damage through an omission, mistake or misfeasance of a Registrar or an official in his office in the execution of his duties, or who is deprived of any land or encumbrance or of an estate or interest therein

(i) through the bringing of it under this Act,

(ii) by the registration of another person as owner of the land or encumbrance, or

(iii) by an error, omission or misdescription in a certificate of title,

and who by this Act is barred from bringing an action for the recovery of the land or encumbrance or interest therein,

may bring an action against the Registrar of the district in which the land is situated for the recovery of damages.

There are two grounds for a claim for compensation under section 158 that are relevant to this discussion. One is Registrar's error. The other is deprivation of land due to the operation of the Land Titles Act. ${ }^{15}$ The claim for deprivation can be made only if the claimant is barred by the Act from recovering the land.

\footnotetext{
12. Ibid.

13. Section 165 of the Act imposes a limitation of $\$ 31,000,000$ plus or minus the net flow of funds into or out of the assurance fund since March 31,1983 . The $\$ 31,000,000$ was an estimate of the amount by which, up to 1983 , fees paid into the fund had exceeded claims paid out.

14. Land Titles Act, supra note 6.

is. Supra note 6.
} 
Mrs. Hill's principal claim was for deprivation of land. She did not lose her ownership, except temporarily, but her fee simple interest was subordinated to the mortgage. The Court of Appeal treated that subordination as deprivation. The court referred to the broad definition of land in section $1(\mathrm{n})$ of the Land Titles Act, ${ }^{16}$ and categorized the interest of which she was deprived as all or part of her "equity" or her "ownership." Section 158(b)(ii) $)^{17}$ was therefore satisfied and gave Mrs. Hill a claim for compensation. Subordination is "deprivation." This interpretation is necessary to achieve the purposes of the compensation system. It is not surprising, but is a useful clarification of the law.

When did "deprivation" occur? The chambers judge held that it did not occur until Mrs. Hill was put out of her house. If that was right, Mrs. Hill was not "deprived" of her interest until 1987 and her action was in time. The Court of Appeal, however, held that it was the registration of the mortgage after the forged transfer which "deprived" Mrs. Hill of an estate or interest in land and gave her a right to compensation. ${ }^{18}$

One minor caveat should be entered against the generality of the proposition that the registration of a conflicting interest causes "deprivation." It is that a claim for compensation under section $158^{19}$ depends on the deprived or subordinated owner being a person "barred from bringing an action for the recovery of the land or encumbrance or interest therein. ${ }^{.20}$ This is a condition precedent. For example,

(1) suppose that in Hill, ${ }^{21}$ the fraud had been discovered after the registration of the mortgage but before the mortgage money was advanced. The mortgage, though registered, would not have secured anything and Mrs. Hill could have got it off her title. It seems likely that a court would hold in such circumstances that Mrs. Hill was not barred by the Act from recovering the interest of which she had apparently been deprived by the registration of the mortgage.

(2) in McWhorter v. Registrar, ${ }^{22}$ which the Court of Appeal referred to in Hill, ${ }^{23}$ minerals were wrongly included in a certificate of title issued to a municipality under tax recovery proceedings. At that time, the deprived owner could have recovered the minerals from the municipality. It seems likely that, if the deprived owner had made a claim before the municipality transferred them to a purchaser, a court would have held that the owner was not barred by the Act from recovering the interest.

The Court of Appeal in $\mathrm{Hill}^{24}$ did not specifically address the requirement that the deprived or subordinated owner be prevented from bringing an action for the recovery of

Supra note 6.

Land Titles Act, supra note 6.

Hill, supra note I at 271.

Land Titles Act, supra note 6.

Land Titles Act, supra note 6.

Supra note 1.

(1989), 67 Alta. L.R. (2d) 7 I (C.A.) [hereinafter McWhorter].

Supra note 1.

Supra note 1. 
the land, nor did it quote the part of section 158 that imposes that requirement. It was, of course, obvious from the previous Court of Appeal judgment that Mrs. Hill was barred from recovering the land. ${ }^{25}$ The only point being made here is that $M c W h o r t e r^{26}$ and Hill $^{27}$ should not be taken as authority for what a court will do if a fact necessary to make a deprivation or subordination irrevocable has not yet occurred.

In the result, $\mathrm{Hill}^{28}$ has established that the registration of a conflicting interest that would not have been effective under the general law will be enough to confer a claim for compensation upon a deprived or subordinated owner, at least if the Land Titles Act ${ }^{29}$ prevents that owner from recovering the interest or getting rid of the conflicting interest. If, as in the Hill case, the conflicting registration leaves the owner with an "empty husk" of a registered interest, the later enforcement of the conflicting interest against that "empty husk" does not revive the claim for compensation or confer a new one. ${ }^{30}$

The Court of Appeal also held that Mrs. Hill had a claim because of Registrar's mistake, presumably under section $158(a){ }^{31}$ The court said: ${ }^{32}$

[The Act] allows only damages where there has been "an omission, mistake or misfeasance of a Registrar," or "the registration of another person as owner of the land or encumbrance." Those two things happened in 1977.

The Registrar's "mistake" was to accept the forged transfer for registration. This deprived Mrs. Hill of her ownership entirely and made the registration of a valid mortgage possible. $^{33}$

Did the Registrar make a "mistake" within the meaning of section 158(a)? $?^{34}$ The land registration system requires Registrars to accept documents that meet certain formal requirements, and there is no suggestion in the judgment that the Registrar failed to see that those requirements were met in Hill. ${ }^{35}$ A Registrar who insisted on investigating all

25. It is only in an action for deprivation that the plaintiff, as a condition of recovery, must be barred by the Act from recovering the land. That might suggest that bringing an action based on the alternative ground of Registrar's mistake would avoid the application of that condition. But a court would probably hold that if the land is recoverable the plaintiff has not suffered the damage of losing the land.

Supra note 22.

Supra note 1.

Supra note 1.

Supra note 6.

The court said that if it was wrong in holding that deprivation took place on registration and that enforcement of the mortgage started a new time running, it was only for a right to sue for the value of the "empty husk," i.e. for nominal damages.

Land Titles Act, supra note 6.

Supra note 1 at 272.

The registration of the transfer was the original "deprivation," but, as noted above, the property was transferred back to Mrs. Hill. The Court of Appeal said at 271 of its judgment "the significant deprivation was the registration of the mortgage."

Land Titles Act, supra note 6.

Supra note 1. 
signatures sufficiently to guarantee that all documents were duly authorized would paralyze and stultify the land registration system. The Registrar did what is expected of Registrars and, in that sense, did not make a mistake. ${ }^{36}$ But the Registrar thought that Mrs. Hill had signed the transfer and would not have registered the transfer if they had known that her signature was forged. In that sense, the Registrar made a mistake.

The court referred to Registrar's mistake only in its discussion of the question whether the final judgment in the foreclosure action was a fact necessary to complete Mrs. Hill's claim against the assurance fund (which it was not). It did not otherwise refer to Registrar's mistake. No other reference was necessary because the "deprivation," whatever its cause, gave Mrs. Hill a claim for compensation, and the loss caused by the "mistake" was the "deprivation." Any discussion of Registrar's mistake in accepting an unauthorized document is academic if all that the mistake leads to is deprivation. But the Hill ${ }^{37}$ case is at least some authority for the proposition that the acceptance by the Registrar of a document that is apparently in order but is in fact forged is a "mistake" under section $158^{38}$ that, if it causes loss or damage, gives rise to a claim for compensation from the assurance fund.

\section{APPLICABILITY OF THE DISCOVERABILITY RULE}

The essential question in $\mathrm{Hill}^{39}$ was whether time started running under section 168(1) of the Land Titles Act on or before April 26, 1982 (her action against the Registrar having been brought on April 26, 1988). The subsection reads as follows: ${ }^{40}$

168(1) No action for damages under this Act shall be brought against the Registrar

(a) by reason of the deprivation of land unless it is brought within 6 years from the date when the deprivation took place.

(b)

by reason of any error, omission or misdescription in a certificate of title, unless it is brought within 6 years of the time when the error, omission or misdescription was made, or

(c) for any other reason, unless it is brought within 6 years from the date when the cause of action arose.

In Hill, ${ }^{41}$ as we have seen, the deprivation occurred when the mortgage was registered, that is, on May 16, 1977, or at latest, when the mortgage money was advanced. The

In Shorey v. Love, [1938] 3 D.L.R. 534 (Man. K.B.) it was held that Registrar was not liable for loss occasioned by issuing a certificate of charge upon a forged transfer of mortgage. The principle was recognized in Ficke v. Spence, [1922] I W.W.R. 1271 (Sask. K.B.).

37. Supra note 1.

38. Land Titles Act, supra note 6.

39. Supra note 1.

40. Supra note 1.

41. Supra note 1. 
Registrar's "mistake" and the loss or damage sustained by Mrs. Hill by reason of that "mistake" occurred at the same time..$^{42}$ Therefore, if section $168(1)^{43}$ means what it says, it prevented Mrs. Hill from bringing action against the Registrar after May of 1983.

But, under judicial interpretation, statutes of limitations do not mean what they say. As noted at the beginning of this comment, the Supreme Court of Canada said in Rafuse ${ }^{44}$ that in a statute of limitations, a reference to the time when a cause of action arises is a reference to the time at which "the material facts on which it is based have been discovered or ought to have been discovered by the plaintiff by the exercise of reasonable diligence. ${ }^{145}$ The Supreme Court did not suggest that this interpretation was based on what a limitations statute means or what the enacting Legislature meant. Instead, it based the interpretation on "the injustice of a law which statute-bars a claim before the plaintiff is even aware of its existence. ${ }^{146}$ It made a conscious policy decision to introduce a judge-made "discoverability" rule which the Legislature had not introduced and which is not consistent with the words used by the Legislature.

Did the "discoverability" rule apply in Hill ${ }^{47}$ The Court of Appeal used language that suggested that the rule did apply: ${ }^{48}$

Even if one thought that Mrs. Hill did not know the facts until the mortgagee testified or the Court of Queen's Bench spoke, there is no real injustice here. Mrs. Hill did not sue for almost three years after that. At the time of trial of the foreclosure suit, six years from discovery in November, 1981 still had two years to run.

If it was the availability of a limitation period based on "discoverability" that avoided injustice, the "discoverability" rule must have applied. But the court formally refrained from deciding whether or not it did apply: ${ }^{49}$

It is not clear whether the limitation period is extended until a plaintiff could not reasonably have discovered the facts giving rise to the claim. But I need not decide that one way or the other, as it does not affect the result in this case.

The reason that the question of "discoverability" did not affect the result was that "discoverability," in the court's view, occurred more than 6 years before Mrs. Hill started

42. The Court of Appeal, supra note 1 at 1 said that the forged transfer was registered on May 9, 1977, and that the mortgage lender agreed to give a mortgage on the same date, while the court, in its earlier judgment, supra note 10 at 370 said that both documents were dated May 9, 1977 and registered on May 16, 1977. Nothing turns on the difference.

Land Titles Act, supra note 6.

Supra note 3.

The "discoverability" rule is further discussed in K.M. v. H.M. (1993), 96 D.L.R. (4th) 289 (S.C.C.), but the discussion does not affect Hill v. Registrar.

Per Wilson J., supra note 2 at 40, quoted by Le Dain J., supra note 3 at 223.

Supra note 1.

Supra note 1 at 270 . Emphasis is added.

Supra note 1 at 269 . Probably "until" should be "while," or alternatively the "not" is in error, but the reference is clearly to the "discoverability" rule. 
her action. The 6-year period had therefore run whether it started with the deprivation or whether it started with "discoverability." In the result, the Hill ${ }^{50}$ case is not authority about the application of the "discoverability" rule to a claim for compensation from the assurance fund, though, as we will see, it is authority about the content of the "discoverability" rule where it does apply.

Does the "discoverability" rule apply to an action for compensation from the assurance fund? As noted, it is a judge-made rule. If the judges made the rule, they can say to what statutes of limitations it applies. Le Dain J.'s language in Rafuse ${ }^{51}$ was broad: "Kamloops laid down a general rule that a cause of action arises for the purposes of a limitation period"52 when the discoverability rule is satisfied.

Now, section $168(1)^{53}$ is about "limitation periods" in the usual meaning of that term. More specifically:

- an action for Registrar's mistake that does not fall within section $168(1)(b)^{54}$ falls within section $168(1)(c),{ }^{55}$ and the limitation period is accordingly " 6 years from the date when the cause of action arose." Those are the precise words to which Le Dain J. applied the "discoverability" rule, and the rule should therefore apply.

- an action for "deprivation" falls within section 168(1)(a), ${ }^{56}$ and the limitation period is accordingly "6 years from the date when the deprivation took place." Section $168(1)(a)^{57}$ does not use the precise words "when the cause of action arose." But, from a limitations policy point of view, the divergence of wording creates a distinction without a difference. And, it seems likely that when the point comes up for decision a court will hold that the there is no reason why section $168(1)(a)^{58}$ should prescribe a different limitation period than section $168(1)(c),{ }^{59}$ and will apply the "discoverability" rule to an action for compensation for deprivation.

It seems likely that a court would hold that the "discoverability" rule applies to an action for compensation under section $168(1){ }^{60}$

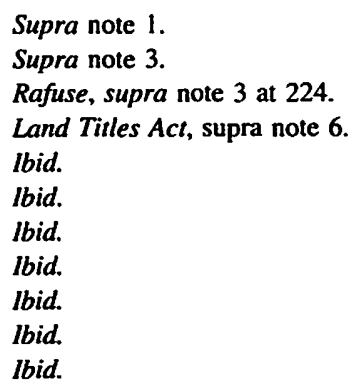




\section{EFFECT OF THE DISCOVERABILITY RULE}

Must all the facts be "discoverable" in order to start time running?

The Court of Appeal said this: ${ }^{61}$

Well before [April 26, 1982], the Law Society wrote a letter to Mrs. Hill saying that there was a mortgage on her title which should not be there, and the she should consult a lawyer as to what to do about that. Any lawyer (and maybe a lay person) could have verified those facts with a few simple land titles searches, even if perchance Mrs. Hill had not yet grasped the facts .... So she knew the relevant facts more than six years before she sued the Fund.

It follows that, in the court's view, knowledge of the registrations and of the contents of the documents was enough to make all the material facts "discoverable" by Mrs. Hill. However, the court went on to consider suggestions that I made in a case comment on the Queen's Bench judgment. ${ }^{62}$ The first of those suggestions was that discovery of the registrations was not discovery of all the material facts. If the mortgage was taken fraudulently, Mrs. Hill would have been entitled to have it set aside and would not have had a claim for compensation from the assurance fund. Therefore, if the discoverability rule applied, the fact that the mortgage was not taken fraudulently was a material fact the "discoverability" of which was needed in order start the time running. I went on to suggest that Mrs. Hill's conduct suggested that she did not know that the mortgage was taken in good faith, because she continued to litigate on the basis that it was not. I suggested also that it would be harsh on Mrs. Hill to say that she "ought to have discovered" that the mortgage had been taken in good faith when she was alleging, presumably in good faith and on the basis of legal advice, that it had not.

The Court of Appeal had this to say about those suggestions: ${ }^{63}$

The case comment also suggests (on p. 1375) that a very material fact was that the transferee was an innocent dupe, ${ }^{6 t}$ and that Mrs. Hill only discovered that when the Queen's Bench gave judgment in July, 1985. I do not agree. When the new mortgagee sued on the mortgage to foreclose, Mrs. Hill counterclaimed against the transferee (among others). The transferee filed defences asserting his innocence on November 4, 1983 and again on April 4, 1984. Mrs. Hill had a chance to examine him for discovery. I do not know whether she did, but she certainly examined other parties for discovery; the transcripts are on the court file. In April, 1985 the transferee filed an affidavit of documents listing many documents and correspondence. The trial was held in May, 1985 and the transferee testified.

61. Supra note 1 at 269.

62. Hill v. South Alberta Land Registration District: The Limitation period for bringing an action to recover damages from the assurance fund (1992), 30 Alta. Law Rev. 1371 at 1375.

63. Hill, supra note 1 .

o. Supra note 1 at 270 . What my case comment actually suggested was that that the lack of fraud of the mortgagee was a material fact, not the innocence of the transferee. This does not affect the discussion, as similar reasoning would apply to the mortgage lender. As lack of good faith on the part of the transferee would not of itself have made the mortgage invalid, I propose to assume throughout that the Court of Appeal meant to refer to the mortgagee. 
It is not clear whether the court disagreed with my suggestion that the mortgage lender's good faith was a "very material fact," or with my suggestion that the existence of that good faith did not become "discoverable" until the trial judgment, or whether it disagreed with both suggestions. The rest of the Court of Appeal's paragraph deals with the time of "discoverability" and suggests that that is where the disagreement lies. ${ }^{65}$ But, if we assume for the moment that I was right in saying that good faith was "very material" and if the fact of good faith became "discoverable" only on the earliest date mentioned in the passage, November 4, 1983, Mrs. Hill's action against the Registrar was in time because she brought the action less than 6 years after that date. Even if the mortgage lender's statement of claim in the foreclosure action made the mortgage lender's good faith "discoverable," Mrs. Hill was in time, as the statement of claim was issued in September, 1982 and she brought her action less than 6 years after that. So it would seem that the court must have intended to say one of the following two things:

- that it was not a material fact that the mortgagee had not engaged in fraud, or

- that Mrs. Hill ought to have discovered, by the exercise of reasonable diligence, from the fact of registration of the forged transfer and the mortgage (which was the information she had before April 26, 1982), that the mortgagee had not engaged in fraud, so that all the material facts were "discoverable" from the facts that she then had.

The court then went on to say that "discoverability" does not call for certainty.

It does not require discovery at all: it says something else will do instead. It suffices that "the material facts facts on which [the cause of action] is based . . o ought to have been discovered by the Plaintiff by the exercise of reasonable diligence ..." Central Trust v. Rafuse [1986] 2 S.C.R. 147, 224. If the plaintiff is told a fact by someone who is likely to know, ${ }^{66}$ surely that makes the fact known or discoverable, even if someone else ${ }^{67}$ disputes the fact. Very few people who sue have perfect certainty. ${ }^{68}$

This is consistent with what Le Dain J. said in Rafuse: he said that the challenge to the mortgage in the foreclosure action was ". . . the earliest that it can be said that the appellant discovered or should have discovered the respondents' negligence by the exercise of reasonable diligence....."

There is, however, a difference between the fact situation in Rafuse ${ }^{70}$ and the fact situation in Hill." It has to do with Mrs. Hill's state of mind. I think that it is permissible to infer from her conduct that she believed, though mistakenly, that the

So does a reference two paragraphs down, supra note 1 at 270 .

Presumably in Hill, the transferee or mortgage lender, depending on whose lack of fraud was material.

Presumably Mrs. Hill, as she was the only one who disputed the lack of fraud.

Hill, supra note 1 at 270.

Rafuse, supra note 3 at 224.

Supra note 3.

Supra note 1. 
mortgage was not taken in good faith. If that cannot be inferred, it can be assumed for the purposes of argument because the court's decision applied whatever her actual state of mind: there is nothing in the decision to suggest that it would have made any difference to the result if it had been proved that Mrs. Hill believed that the mortgage was not taken in good faith.

So Mrs. Hill's subjective belief was immaterial. The court's opinion was that Mrs. Hill ought, by the exercise of reasonable diligence, to have discovered all the material facts, including the mortgagee's lack of fraud, which was necessary to make the mortgage valid so as to deprive her of her land. The test is the objective test of the reasonable person. It is not to the point that Mrs. Hill's subjective belief that the mortgage was not taken in good faith prevented her from "discovering" the facts necessary for her claim against the assurance fund.

Another passage in the Court of Appeal's judgment throws some light on the court's view of the purpose of the "discoverability" rule: ${ }^{72}$

Nor can I see any legal or practical impediment to Mrs. Hill's having sued the Fund years before she did. It must have been obvious that if the mortgagee succeeded, that would be her only remaining recourse.

The mortgagee relentlessly pressed the suit forward to trial, and even moved for summary judgment.

The passage suggests that the court was looking beyond the formal statement of the "discoverability" rule to its view of the policy behind the rule. The question is not so much whether or not the plaintiff knew or ought to have known the material facts as whether or not the plaintiff knew or ought to have known enough to enable a reasonable person to make an informed decision about bringing an action. But the court at this point was not addressing the question of whether Mrs. Hill's claim was statute-barred, but rather the question of whether the statute-barring of her claim created injustice. Thus the passage cannot be taken as a formal gloss on the "discoverability" rule.

K.M. v. H.M.

In K.M. v. H.M. ${ }^{73}$ the Supreme Court held that the material facts of a cause of action are not "discoverable" by a plaintiff who knows the underlying facts but is psychologically unable to make the connection between the underlying facts and the harm suffered by the plaintiff. This is not necessarily inconsistent with Hill. ${ }^{74}$ The Supreme Court might not apply K.M. v. H.M. ${ }^{75}$ to a case involving a less emotive cause of action. It might not apply it to a case in which a plaintiff who should know the underlying facts has formed a belief that is contrary to them. But there is some difference in approach, and it remains

73. (1993), 96 D.L.R. (4th) 289. In Stubbings v. Webb, [1993] All E.R. 322 the House of Lords doubted that a plaintiff in a childhood sexual abuse case would not realise that she had suffered sufficiently serious abuse to justify bringing an action, and it did not even consider the possibility that a "discoverability" rule would have applied anyway. 
to be seen whether the more restrictive approach suggested by $H_{i l l}{ }^{76}$ or the more expansive approach suggested by K.M. v. H.M. ${ }^{77}$ will be followed.

\section{WHETHER "DISCOVERABILITY" CAN INCLUDE LAW}

One other point should be mentioned, though it was not important to the result in the Hill case. The court, referring to my case comment said this: ${ }^{78}$

The case comment is ambiguous; it may suggest that Mrs. Hill could not reasonably discover until the Court of Appeal declared the mortgage valid, or alternatively, until the Court of Queen's Bench declared that it was done in good faith ... If that involves law, I disagree . . . Discoverability refers to facts, not law. Error or ignorance of law, or uncertainty of the law, does not postpone any limitation period.

It will be remembered that the reason for the "discoverability" rule is the "injustice of a law which statute-bars a claim before the plaintiff is even aware of its existence." ${ }^{179}$ This reason is based on the fact of non-awareness, not on its cause. On the face of it, the injustice is no less because it is ignorance of law rather than ignorance of fact that prevents the plaintiff from becoming aware of the existence of the cause of action.

But the court is, in my submission, right in restricting the "discoverability" rule to the "discoverability" of the material facts. The policy reasons behind limitations statutes are valid and important, and they require that a plaintiff bear some responsibility for bringing forward claims within a reasonable period of time. If a plaintiff knows that they have suffered damage or injury and knows that the damage or injury resulted from the conduct of another person, he or she should take action within a reasonable time. For one thing, it would be enormously difficult for defendants to show that plaintiffs knew or ought to have known about the relevant law. For another, judicial decisions continually change the law and often confer new remedies or make old ones more widely available, ${ }^{80}$ and statutes occasionally change the law with retroactive effect. Allowing plaintiffs to sue for old claims under the new rules would create much injustice to defendants. Extending the "discoverability" rule to include "discoverability" of law would defeat the policy objectives of limitations statutes. Not extending it is an exercise of appropriate judicial restraint.

The Court of Appeal's statement restricting "discoverability" to fact is consistent with

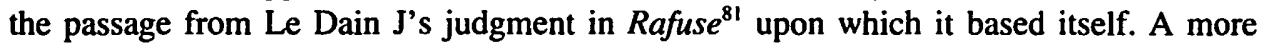
extensive quotation of that passage is as follows: ${ }^{82}$

Supra note 1.

Supra note 73.

Supra note 1 at 270 . Though a passage in the case comment might be read otherwise, I did not intend to suggest that non-discoverability of law does or should stop a limitation period from running. That is immaterial to the discussion. What is material is the Court of Appeal's dictum.

Supra note 36.

The theory that a judicial decision that breaks new ground merely discloses what the law was before the decision was rendered is not entertained as widely as it was.

Supra note 3.

lbid. at 224. 
I am thus of the view that the judgment of the majority in Kamloops laid down a general rule that a cause of action arises for the purposes of a limitation period when the material facts on which it is based have been discovered or ought to have been discovered by the plaintiff by the exercise of reasonable diligence, and that that rule should be followed and applied to the appellant's cause of action in tort ... Since the respondents gave the Nova Scotia Trust Company a certificate on January 17, 1969, that the mortgage was a first charge on the Stonehouse property, thereby implying that it was a valid mortgage, the earliest that it can be said that the appellant discovered or should have discovered the respondents' negligence by the exercise of reasonable diligence was in April or May 1977 when the validity of the mortgage was challenged in the action for foreclosure. Accordingly the appellant's cause of action in tort did not arise before that date and its action for negligence against the respondents is not statute barred.

This statement seems to be perfectly clear: "discoverability" means discoverability of facts. "Discoverability" does not include "discoverability" of law.

But there is a difficulty. It is this: in Rafuse $e^{83}$ itself, time did not start to run until the plaintiff mortgage lender discovered or ought to have discovered some law, and it began to run at the time of that actual or imputed discovery.

The Supreme Court held that the negligence of the solicitors in Rafuse $e^{84}$ consisted of accepting and certifying as valid a mortgage that was void because the proceeds of the mortgage loan were used to pay for shares of the mortgagor corporation. The mortgage lender client knew at the time that that was the purpose of the loan; that is, they knew every tangible material fact. What they did not know was that the Nova Scotia Companies $A c t^{85}$ made the mortgage illegal and void. When they ought to have known that the Act had that legal effect, time began to run. The mortgage lender's action, though commenced more than 6 years after the cause of action was complete, was commenced less than 6 years after the illegality of the mortgage became "discoverable." The mortgage lender was protected by the "discoverability" rule.

The difficulty can be overcome this way. The mortgage lender did not know that there had been a loss until it discovered that the mortgage was invalid. Further, it did not know that the lawyers had been negligent. Negligence, although it involves a legal duty, has traditionally been treated as a question of fact. Therefore negligence is a fact. The solicitors' negligence was a material fact the occurrence of which was not "discoverable" until the mortgage was challenged.

This reasoning is rather awkward. From the beginning, the mortgage lender knew everything material that the solicitors had done. What they did not know was that a legal element existed that converted what the solicitors had done into negligence. It was discovery of the legal element that made both the loss and the negligence "discoverable."

But it is probably safe to accept that the "discoverability" rule is restricted to facts. Le Dain J. framed it that way, and the Court of Appeal has now emphatically stated it that

Ibid.

85. Companies Act, R.S.N.S. 1989, c. 81. 
way. Le Dain J. said, in the passage quoted above, that it was the actual or imputed discovery of the solicitors' negligence which started the time running. The "discoverability" rule is one of judicial policy and the rule is therefore what the courts say it is. Since Rafuse ${ }^{86}$ stare decisis may require the rule to be applied to a case in which ignorance of law leads to non-discoverability of material fact, but that is an uncommon case and does not amount to an extension of the "discoverability" rule to cover nondiscoverability of law.

\section{CONCLUSION}

The following propositions flow from Kamloops, ${ }^{87}$ Rafuse ${ }^{88}$ and Hill: ${ }^{89}$

1. A limitation period will not commence to run until the plaintiff's cause of action is "discoverable."

2. The rule is judge-made. It is based on the injustice of limitations periods and is not dependent upon what limitations statutes say or mean. ${ }^{90}$ The rule is therefore under the control of the courts and can be shaped and applied according to judicial policy.

3. A plaintiff's cause of action is not "discoverable" until he or she has discovered, or ought by the exercise of reasonable diligence to have discovered, the material facts on which the cause of action is based. This is the statement in Rafuse. ${ }^{91}$

4. While the statement of the rule in Rafuse $e^{22}$ is limited to the "discoverability" of facts, and while the Court of Appeal in Hill ${ }^{33}$ specifically said that the rule is limited to facts, it may be that non-discoverability of law will lead to "non-discoverability" of fact so as to prevent a limitation period from running. This is what happened in Rafuse. ${ }^{94}$

5. The "discoverability" rule is satisfied with less than certain knowledge. Specifically, if an opposite party makes an allegation in the course of a proceeding, probably including an allegation in a pleading, the fact alleged is "discoverable" even if the plaintiff believes the contrary to be true. This is clear from dicta in Hill $^{\text {95 }}$ and is supported by Rafuse $^{96}$ though not stated in those terms.

Supra note 3.

Supra note 2.

Supra note 3.

Supra note 1.

It is possible that if a legislature enacts legislation providing for a limitation period starting with discovery or "discoverability" and also provides for a long-stop limitation period, the judge-made "discoverability" rule will not apply to the latter: see Bera v. Marr (1986), 27 D.L.R. (4th) 161 (B.C.C.A.). But this was a pre-Rafuse decision. 
6. Where a mortgage is binding unless the mortgagee participated in fraud, it seems that for the purposes of the "discoverability" rule, one or both of the following statements are true:

(a) the lack of fraud is not a material fact for the purposes of the "discoverability rule," or

(b) the lack of fraud is "discoverable" from the fact that the mortgage is registered.

This is by inference from the statement in $\mathrm{Hill}^{97}$ that "discoverability" was complete by November 1981 .

7. Query whether the "discoverability" rule is satisfied if it becomes apparent that if an opposite party succeeds in a lawsuit the plaintiff has a cause of action against a third party. A passage in $\mathrm{Hill}^{98}$ suggests that the Court of Appeal would be sympathetic to the proposition that it is satisfied.

8. Parties who suffer injury should ensure that they commence all possible legal proceedings within the relevant limitation periods, or take alternative ways of protecting themselves, and should not rely on the "discoverability" rule. This has always been true. 